\title{
The Effect of Air Preheating in a Biomass CFB Gasifier using ASPEN Plus Simulation
}

Wayne Doherty

Technological University Dublin, wayne.doherty@tudublin.ie

Anthony Reynolds

Technological University Dublin, anthony.reynolds@tudublin.ie

David Kennedy

Technological University Dublin, david.kennedy@tudublin.ie

Follow this and additional works at: https://arrow.tudublin.ie/engschmecart

Part of the Mechanical Engineering Commons

\section{Recommended Citation}

Doherty, W., Reynolds, A., Kennedy, D.: The Effect of Air Preheating in a Biomass CFB Gasifier Using ASPEN Plus Simulation. Biomass and Bioenergy (In Press), doi:10.1016/j.biombioe.2009.05.004.

This Article is brought to you for free and open access by the School of Mechanical and Design Engineering at ARROW@TU Dublin. It has been accepted for inclusion in Articles by an authorized administrator of ARROW@TU Dublin. For more information, please contact arrow.admin@tudublin.ie, aisling.coyne@tudublin.ie, gerard.connolly@tudublin.ie.

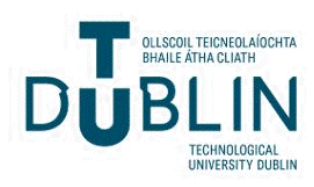




\title{
School of Mechanical and Transport Engineering Conference proceedings
}

\section{The effect of air preheating in a biomass CFB gasifier using ASPEN Plus simulation}

\author{
Wayne G. Doherty* Anthony Reynolds ${ }^{\dagger}$
}

David Kennedy ${ }^{\ddagger}$

*Dublin Institute of Technology, wayne.doherty@dit.ie

$\dagger$ Dublin Institute of Technology, anthony.reynolds@dit.ie

‡Dublin Institute of Technology, david.kennedy@dit.ie This paper is posted at ARROW@DIT.

http://arrow.dit.ie/engschmeccon/1 


\section{— Use Licence}

\section{Attribution-NonCommercial-ShareAlike 1.0}

You are free:

- to copy, distribute, display, and perform the work

- to make derivative works

Under the following conditions:

- Attribution.

You must give the original author credit.

- Non-Commercial.

You may not use this work for commercial purposes.

- Share Alike.

If you alter, transform, or build upon this work, you may distribute the resulting work only under a license identical to this one.

For any reuse or distribution, you must make clear to others the license terms of this work. Any of these conditions can be waived if you get permission from the author.

Your fair use and other rights are in no way affected by the above.

This work is licensed under the Creative Commons Attribution-NonCommercialShareAlike License. To view a copy of this license, visit:

- URL (human-readable summary):

http://creativecommons.org/licenses/by-nc-sa/1.0/

- URL (legal code):

http://creativecommons.org/worldwide/uk/translated-license 


\title{
The effect of air preheating in a biomass CFB gasifier using
}

\author{
ASPEN Plus simulation \\ Wayne Doherty *, Anthony Reynolds, David Kennedy \\ Department of Mechanical Engineering, \\ Dublin Institute of Technology, Bolton Street, Dublin 1, Ireland
}

\begin{abstract}
In the context of climate change, increasing efficiency and energy security, biomass gasification is likely to play an important role in energy production. Atmospheric circulating fluidised bed (CFB) technology was selected for the current study. The primary objective of this research is to develop a computer simulation model of a CFB biomass gasifier that can accurately predict gasifier performance under various operating conditions. An original model was developed using ASPEN Plus (Advanced System for Process ENgineering Plus). The model is based on Gibbs free energy minimisation. The restricted equilibrium method was used to calibrate the model against experimental data. This was achieved by specifying the temperature approach for the gasification reactions. The model predicts syngas composition, process conversion efficiency and syn-gas heating values in good agreement with experimental data from a laboratory rig. Operating parameters were varied over a wide range. Parameters such as equivalence ratio (ER), temperature, air preheating, biomass moisture and steam injection were found to influence product gas (syn-gas) composition, syn-gas heating value, and process conversion efficiency. The results indicate an ER and temperature range over which hydrogen $\left(\mathrm{H}_{2}\right)$ and carbon monoxide $(\mathrm{CO})$ production is maximised, which in turn ensures a high heating value and cold gas efficiency (CGE). Gas heating value was found to decrease with ER. Air preheating increases $\mathrm{H}_{2}$ and CO production, which increases gas heating value and gasifier CGE. Air preheating is more effective at low ERs. A critical air temperature exists after which additional preheating has little influence. Steam

* Corresponding author. Tel.: +353 1 4022976; fax: +3531 4023991.

E-mail address: wayne.doherty@dit.ie (W. Doherty).
\end{abstract}


has better reactivity than fuel bound moisture. Increasing moisture degrades gasifier performance therefore the input fuel should be pre-dried. Steam injection should be employed if a $\mathrm{H}_{2}$ rich syn-gas is desired.

Keywords: Biomass gasification; Modelling; Circulating fluidised bed; Gibbs free energy minimisation; Equivalence ratio; Steam injection

\section{Introduction}

Biomass is of major interest as a renewable energy source in the context of both climate change mitigation and energy security. Energy security is of utmost importance and is vital for any country's continued economic growth. Currently Ireland imports $90 \%$ of its energy [1]. According to a recent study, oil and gas prices are set to double by 2050 [2]. Also global energy demand is set to more than double by the middle of the century, fuelled by the rapid increase in the energy demand of developing countries. Another study, World Energy Outlook [3] predicts similar trends. This study predicts a 53\% increase in global energy demand by $2030,70 \%$ of which will come from China, India and other developing countries and a 55\% increase in carbon dioxide $\left(\mathrm{CO}_{2}\right)$ emissions. Biomass gasification coupled with other renewable energy options could cut dependency on imported energy and would help to ensure energy security.

Gasification is a process for converting carbonaceous materials to a combustible or synthetic gas [4]. It can be considered an upgrading process that takes in a solid which is difficult to handle, strip it of undesirable constituents and convert it into a gaseous product that can be handled with maximum convenience and minimum cost and can readily be purified to a clean fuel or feedstock for synthesis of other chemicals [5]. Gasification occurs when oxygen $\left(\mathrm{O}_{2}\right)$ or air and steam or water is reacted at high temperatures with available carbon in biomass or other carbonaceous material within a gasifier. The syngas produced can be combusted in an engine or gas turbine to generate electricity and heat or more recently syn-gas is considered a candidate fuel for fuel cell applications. Air gasification produces a poor quality gas with regard to the heating value, around 4-7 $\mathrm{MJ} \mathrm{m}^{-3}$ higher heating value (HHV), while $\mathrm{O}_{2}$ and steam blown processes result in a syn-gas with a heating value in the range of $10-18 \mathrm{MJ} \mathrm{m}^{-3}$ (HHV) [6]. However, gasification with pure $\mathrm{O}_{2}$ is not practical for biomass gasification due to prohibitively high 
costs for $\mathrm{O}_{2}$ production using current commercial technology (cryogenic air separation). This has encouraged research of novel gasification processes such as the dual indirectly heated fluidised bed [6-9]. The modelling of air gasification is conducted in this research work.

Stoichiometric combustion occurs when all the carbon in the fuel is converted to $\mathrm{CO}_{2}$ and there is no excess $\mathrm{O}_{2}$ left over. The basis of gasification is to supply less oxidant than would be required for stoichiometric combustion of a solid fuel. The resulting chemical reactions produce a mixture of carbon monoxide $(\mathrm{CO})$ and hydrogen $\left(\mathrm{H}_{2}\right)$, both of which are combustible. The energy value of this gaseous fuel is typically $75 \%$ of the chemical heating value of the original solid fuel. In addition, the syn-gas temperature will be substantially higher than the original solid fuel due to the gasification process. The process of biomass gasification is represented by the reactions given in Table 1.

Table 1

Gasification reactions

\begin{tabular}{|c|c|c|c|}
\hline Reaction & Heat of reaction ${ }^{a}$ & $\begin{array}{l}\text { Reaction } \\
\text { name }\end{array}$ & $\begin{array}{l}\text { Reaction } \\
\text { number }\end{array}$ \\
\hline $\begin{array}{l}\text { Heterogeneous reactions: } \\
\mathrm{C}+0.5 \mathrm{O}_{2}=\mathrm{CO} \\
\mathrm{C}+\mathrm{CO}_{2} \leftrightarrow 2 \mathrm{CO} \\
\mathrm{C}+\mathrm{H}_{2} \mathrm{O} \leftrightarrow \mathrm{CO}+\mathrm{H}_{2} \\
\mathrm{C}+2 \mathrm{H}_{2} \leftrightarrow \mathrm{CH}_{4} \\
\text { Homogeneous reactions: } \\
\mathrm{CO}+0.5 \mathrm{O}_{2}=\mathrm{CO}_{2} \\
\mathrm{H}_{2}+0.5 \mathrm{O}_{2}=\mathrm{H}_{2} \mathrm{O} \\
\mathrm{CO}+\mathrm{H}_{2} \mathrm{O} \leftrightarrow \mathrm{CO}_{2}+\mathrm{H}_{2} \\
\mathrm{CH}+\mathrm{H}_{2} \mathrm{O} \leftrightarrow \mathrm{CO}+3 \mathrm{H}_{2} \\
\mathrm{Hydrogen} \text { sulphide }\left(\mathrm{H}_{2} \mathrm{~S}\right) \\
\text { and ammonia }\left(\mathrm{NH}_{3}\right) \\
\text { formation reactions: } \\
\mathrm{H}_{2}+\mathrm{S}=\mathrm{H}_{2} \mathrm{~S} \\
0.5 \mathrm{~N}_{2}+1.5 \mathrm{H}_{2} \leftrightarrow \mathrm{NH}_{3}\end{array}$ & $\begin{array}{l}\left(-111 \mathrm{MJ} \mathrm{kmol}^{-1}\right) \\
\left(+172 \mathrm{MJ} \mathrm{kmol}^{-1}\right) \\
\left(+131 \mathrm{MJ} \mathrm{kmol}^{-1}\right) \\
\left(-75 \mathrm{MJ} \mathrm{kmol}^{-1}\right) \\
\\
\left(-283 \mathrm{MJ} \mathrm{kmol}^{-1}\right) \\
\left(-242 \mathrm{MJ} \mathrm{kmol}^{-1}\right) \\
\left(-41 \mathrm{MJ} \mathrm{kmol}^{-1}\right) \\
\left(+206 \mathrm{MJ} \mathrm{kmol}^{-1}\right)\end{array}$ & $\begin{array}{l}\text { Char partial combustion } \\
\text { Boudouard } \\
\text { Water-gas } \\
\text { Methanation } \\
\mathrm{CO} \text { partial combustion } \\
\mathrm{H}_{2} \text { partial combustion } \\
\mathrm{CO} \text { shift } \\
\text { Steam-methane reforming }\end{array}$ & $\begin{array}{l}\text { (R1) } \\
\text { (R2) } \\
\text { (R3) } \\
\text { (R4) } \\
\text { (R5) } \\
\text { (R6) } \\
\text { (R7) } \\
\text { (R8) }\end{array}$ \\
\hline
\end{tabular}

The gasification process can be split into three linked processes; pyrolysis (also called devolatilisation, thermal decomposition or carbonisation), gasification, and combustion. Gasification and combustion may be combined, for example Di Blasi et al. [11] described gasification as two stages: solid pyrolysis and char conversion (gasification and combustion). Partial combustion is necessary because it supplies the heat required by the endothermic gasification reactions. Pyrolysis occurs in a temperature range of $350-800{ }^{\circ} \mathrm{C}$ and results in the production of char, $\mathrm{CO}, \mathrm{H}_{2}$, methane $\left(\mathrm{CH}_{4}\right), \mathrm{CO}_{2}, \mathrm{H}_{2} \mathrm{O}$, tars and hydrocarbons. Tars are extremely undesirable because they represent a loss of efficiency and degrade downstream plant equipment. If temperatures are high enough some tars will be cracked to form $\mathrm{H}_{2}, \mathrm{CO}$, $\mathrm{CO}_{2}$ and others. The products of pyrolysis are then used in the gasification and combustion reactions. 
To date there has been a lack of research and reporting on biomass gasification, which makes it difficult to design plants. The primary objective of this research was to develop a computer simulation model of a CFB biomass gasifier that can accurately predict gasifier performance under various operating conditions. In this paper an original model of a biomass CFB gasifier developed using the commercial chemical process simulator ASPEN Plus is presented. The model presented is based on Gibbs free energy minimisation. The approach assumes that only a limited number of chemical reactions (R1 to R10) are required with respect to the prediction of syn-gas composition, gas heating value and process efficiency. The influence of operating conditions on gasifier performance was investigated and the results and conclusions from these investigations are presented.

\section{Methodology}

\subsection{Gasifier types and selection}

The differences between classifications are in the movement of the fuel through the vessel, the operating pressures and temperatures and the size and condition of the entering fuel [12]. The primary configurations are moving/fixed bed, fluidised bed, and entrained flow. Atmospheric CFB was selected for the current study because of its near commercial status. This technology is proven for biomass gasification, has potential for scale-up (low MW to over $100 \mathrm{MW}$ ) and high fuel flexibility. The Värnamo biomass integrated gasification combined cycle (BIGCC) demonstration plant, which operated in Sweden from 1996 to 2000, used pressurised CFB gasification technology. Fig. 1 shows a schematic of a typical CFB gasifier.

\subsection{Process simulation software}

ASPEN Plus was selected for modelling the gasifier. This simulation package has been used for modelling coal and biomass power generation systems in many research projects [13-23]. It is a steady state chemical process simulator, which was developed at Massachusetts Institute of Technology (MIT) for the US DOE, to evaluate synthetic fuel technologies. It uses unit operation blocks, which are models of specific process operations (reactors, heaters, pumps etc.). The user places these blocks on a 
flowsheet, specifying material and energy streams. An extensive built in physical properties database is used for the simulation calculations. The program uses a sequential modular (SM) approach, i.e. solves the process scheme module by module, calculating the outlet stream properties using the inlet stream properties for each block. ASPEN Plus has the capability to incorporate Fortran code, written by the user, into the model. This feature is utilised for the definition of non-conventional fuels, e.g. biomass, municipal solid waste (MSW), specific coals and for ensuring the system operates within user defined limits and constraints. User models can be created in Excel or written using Fortran and can be fully integrated into the ASPEN Plus flowsheet.



Fig. 1. Schematic diagram of a CFB biomass gasifier.

\subsection{Uncoupling the gasification process}

To model a CFB gasifier using ASPEN Plus, the overall process must be broken down into a number of sub-processes. For example a model may include the following zones: drying and pyrolysis, 
partial oxidation, and gasification. The modeller may choose to model each of these zones separately or combine them in one unit. Fig. 2 shows the overall gasification process broken down or uncoupled into its sub-processes.

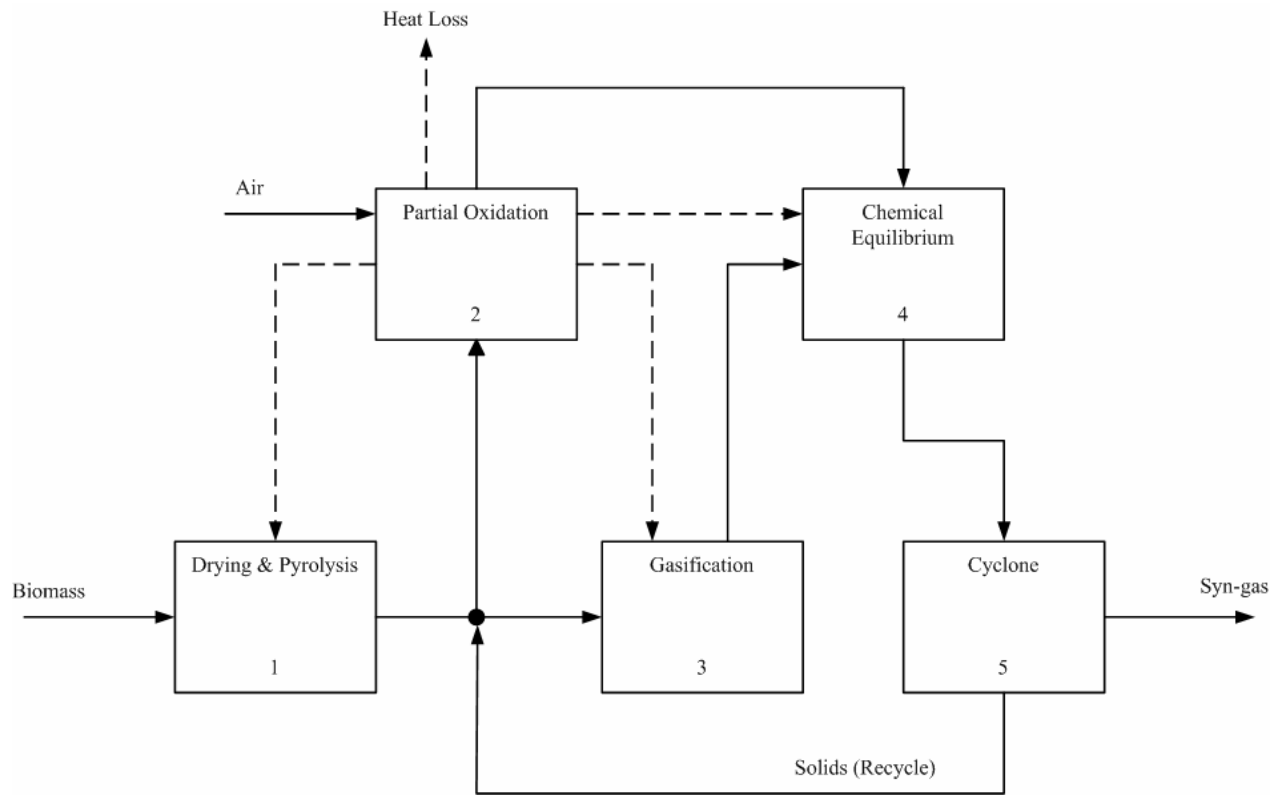

Fig. 2. Uncoupled CFB gasification process.

The drying and pyrolysis zone simulates the first stage of gasification and produces char, $\mathrm{H}_{2}$, $\mathrm{CO}, \mathrm{CH}_{4}, \mathrm{CO}_{2}, \mathrm{H}_{2} \mathrm{O}$, other hydrocarbons, and tars. These products are then either burnt or gasified. The partial oxidation zone simulates the burning of char as well as some $\mathrm{H}_{2}$ and $\mathrm{CO}$, which generates the heat required for all the sub-processes. This heat is represented by broken lines in Fig. 2. A percentage of the heat generated is lost from the system and products other than heat from this zone include $\mathrm{CO}, \mathrm{CO}_{2}$, and $\mathrm{H}_{2} \mathrm{O}$. The third zone, the gasification zone, simulates the gasification reactions, reactions such as the Boudouard, the water-gas and the methanation. The products of both the partial oxidation and the gasification zone are fed into an additional zone. This zone sets the final syn-gas composition, which is composed mainly of $\mathrm{H}_{2}, \mathrm{CO}, \mathrm{CO}_{2}$ and some $\mathrm{CH}_{4}$. In this zone the chemical equilibrium of the gasification reactions is restricted in order to give a realistic syn-gas composition. The final zone, box 5 , represents the $\mathrm{CFB}$ cyclone separator, which separates out and recycles the solids entrained in the gas. 


\section{Modelling}

\subsection{ASPEN Plus flowsheet}

Fig. 3 displays the CFB biomass gasifier ASPEN Plus flowsheet. Table 2 presents a brief description of the unit operation blocks shown in Fig. 3. It gives the ASPEN Plus name, that is the name given to each unit operation block by the software developers, the block ID, which is the name given to each block by the user and a short description.

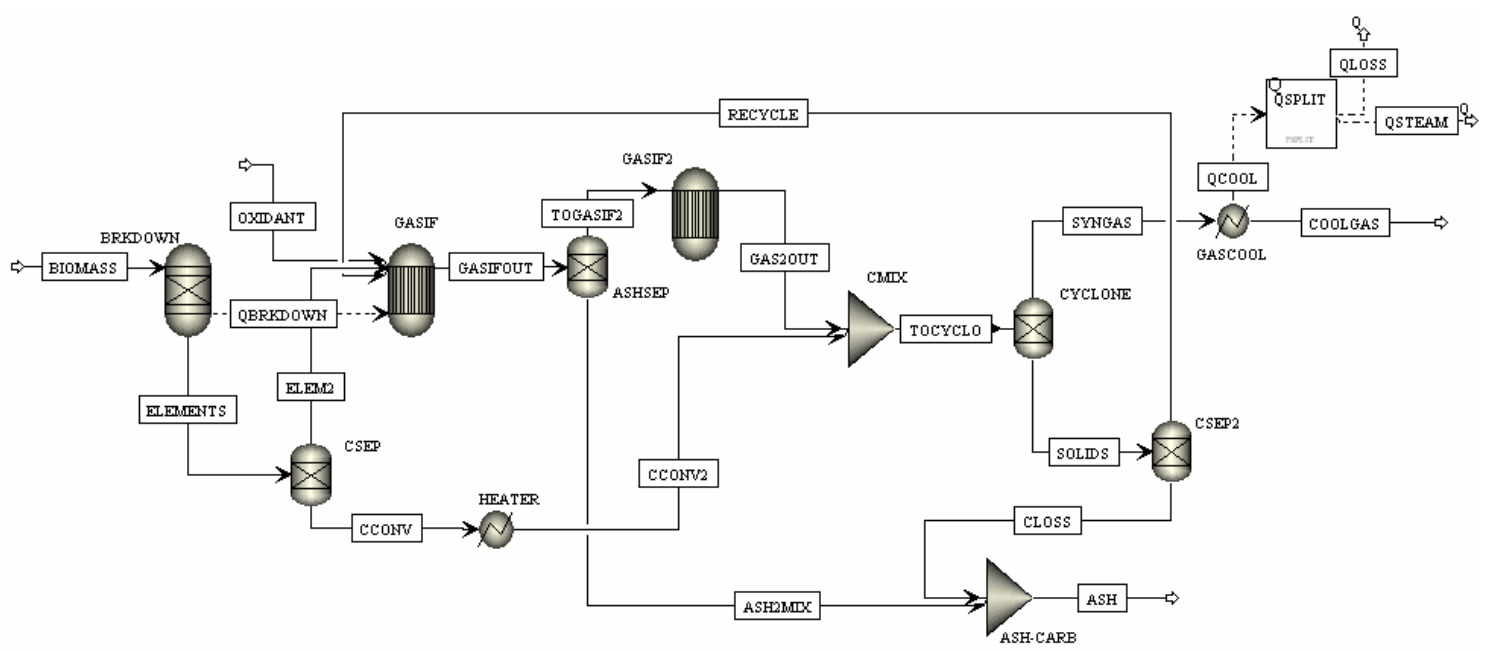

Fig. 3. ASPEN Plus flowsheet of biomass CFB gasifier.

Table 2

Description of ASPEN Plus flowsheet unit operation blocks presented in Fig. 3

\begin{tabular}{|c|c|c|}
\hline $\begin{array}{l}\text { ASPEN } \\
\text { Plus name }\end{array}$ & Block ID & Description \\
\hline RYIELD & BRKDOWN & Yield reactor - converts the non-conventional stream 'BIOMASS' into conventional components \\
\hline \multirow[t]{3}{*}{ SEP2 } & CSEP & Separator - extracts a portion of the carbon contained in the fuel so that it remains un-reacted \\
\hline & CYCLONE & Separator - simulates the CFB cyclone by separating out a specified percentage of the solid carbon \\
\hline & CSEP2 & Separator - extracts a portion of the carbon to simulate carbon loss in the ash, with the rest recycled \\
\hline RGIBBS & GASIF & Gibbs free energy reactor - simulates drying and pyrolysis, partial oxidation, and gasification \\
\hline \multirow[t]{2}{*}{ HEATER } & HEATER & Heater - increases the temperature of the un-reacted carbon to the reactor temperature \\
\hline & GASCOOL & Cooler - simulates syn-gas cooling to a typical gas cleanup temperature \\
\hline \multirow[t]{2}{*}{ MIXER } & CMIX & Mixer - mixes the un-reacted carbon separated in block 'CSEP' with the syn-gas \\
\hline & ASH-CARB & Mixer - mixes the carbon lost with the ash before leaving the system \\
\hline FSPLIT & QSPLIT & $\begin{array}{l}\text { Splitter - splits the heat available from syn-gas cooling in 'GASCOOL' into two heat streams with } \\
\text { one of them representing the heat lost from the gasifier }\end{array}$ \\
\hline
\end{tabular}




\subsection{Model description}

The main model assumptions are: steady state conditions, zero-dimensional model, isothermal (uniform bed temperature), drying and pyrolysis are instantaneous in a CFB [24, 25], char is 100\% carbon (graphite), all of the sulphur reacts to form $\mathrm{H}_{2} \mathrm{~S}$ [6], only $\mathrm{NH}_{3}$ formed no nitrogen oxides considered [6, $12,23]$, cyclone separation efficiency is $85 \%$ [26], $2 \%$ carbon loss in ash [27], and heat loss from the gasifier is equal to $3 \%$ of the total heat input $[16,28,29]$.

From Fig. 3, the stream 'BIOMASS' was specified as a non-conventional stream and the ultimate and proximate analyses were inputted. The stream thermodynamic condition and mass flow rate were also entered. The block 'BRKDOWN' yields are set by a calculator block, which in turn determines the mass flow of each component in the block outlet stream 'ELEMENTS'. The enthalpy of this stream will not equal the enthalpy of the feed stream 'BIOMASS', as the enthalpies of the individual constituents that make up a fuel do not equal the enthalpy of the fuel because chemical bonds etc. are not taken into consideration. The energy value of any heat stream leaving a block is equal to the block heat duty, which is equal to the difference in enthalpy between the inlet and outlet streams. Thus, the heat stream 'QBRKDOWN' was inserted to add back the enthalpy loss to the system.

The function of the next block is to simulate carbon conversion by separating out a specified portion of the carbon from the fuel. Reported carbon conversion for CFB gasifiers in the literature ranged from 90 to $99 \%$ [29-32]. Before this carbon can be mixed with the gas downstream it must be brought up to the gasifier temperature, which is accomplished using the block entitled 'HEATER'. The un-reacted carbon represents solids contained in the product gas that must be removed by the CFB gasifier cyclone or other solids removal steps downstream. In reality there would also be fly ash and bed material entrained in the gas but these components cannot be modelled in ASPEN Plus. Thus, in this model the solid carbon that remains in the syn-gas represents all solids.

The streams 'ELEM2', 'OXIDANT', and 'RECYCLE' enter the block 'GASIF', where pyrolysis, partial oxidation, and gasification reactions occur. The mass flow of air entering the reactor is set using a design specification, which varies the oxidant mass flow rate so that a specific gasifier temperature is achieved. Alternatively, the air mass flow is set by a calculator block that calculates the air flow using a user specified equivalence ratio (ER). ER is defined as the ratio of the actual oxidant mass flow rate to the stoichiometric oxidant mass flow rate. Most existing fluidised bed biomass gasifiers 
operate in the ER range 0.2-0.45 [33]. All the sulphur in the system reacts with $\mathrm{H}_{2}$ to form $\mathrm{H}_{2} \mathrm{~S}$. Due to the low contents of sulphur in the fuel, inaccuracies of this simplification are negligible [6]. The simplification that only $\mathrm{NH}_{3}$ is formed and nitrogen oxides are omitted was adopted in this work. This assumption has been applied by others such as Pickett [12]; Schuster et al. [6]; and Zhu [23]. Char, which is a product of pyrolysis, is assumed to be $100 \%$ carbon (graphite). Demirbaş [34] reported the elemental analysis of various wood chars and the carbon content ranged from 90.5 to 92.1 wt. \%, therefore the assumption is valid.

Ash removal is simulated in the model using the unit operation block 'ASHSEP'. The material stream 'TOGASIF2' is fed to the unit operation block 'GASIF2', which is an 'RGIBBS' reactor. 'RGIBBS' reactors allow restricted equilibrium specifications for systems that do not reach complete equilibrium. Specifying the temperature approach for each reaction results in restricted equilibrium, which means that the syn-gas composition can be adjusted to match data reported in the literature. This approach is well established, it was introduced by Gumz [35]. Reactions (R7), (R8), and (R10) were specified in the 'RGIBBS' reactor.

The next block mixes the un-reacted carbon that was separated upstream with the gas from 'GASIF2' and its product stream is fed to a separator that simulates the operation of the CFB gasifier cyclone. The block 'CYCLONE' was specified so that it removes $85 \%$ of the solid carbon from the gas stream [26]. Zhang and Basu [26] investigated the operation of a CFB cyclone by experiment and developed a model that predicted the cyclone collection efficiency for different particle diameters and gas velocities and showed that the efficiency ranged from 70 to $100 \%$. The average value of $85 \%$ was used in this work. The bottom outlet stream from 'CYCLONE' with the stream name 'SOLIDS' is composed of solid carbon only and is sent to a separator block 'CSEP2'. The top outlet stream, which is called 'SYNGAS', is composed of all the gases from 'GASIF2' and a small amount of solid carbon (15\% of the un-reacted carbon). This material stream represents the final output, i.e. the product gas from the gasifier.

'CSEP2' splits the 'SOLIDS' stream into a recycle stream 'RECYCLE', that is sent back through the gasifier, and another stream named 'CLOSS', which represents the carbon lost from the system in the ash. The recycle was added because in a real CFB gasifier, inerts (bed material and fly ash) and un-reacted char are collected in the cyclone and re-injected into the reaction zone of the gasifier via the return leg (see Fig. 1). The 'CSEP2' split fraction is set by a calculator block using the specification 
that the ash exiting the gasifier contains $2 \%$ carbon [27]. The stream 'CLOSS' is then mixed with the ash in the block 'ASH-CARB'.

The stream 'SYNGAS' is fed to a cooler entitled 'GASCOOL' that cools the gas to the required gas cleanup temperature of $375{ }^{\circ} \mathrm{C}$ [36]. The energy that would be lost through cooling could be recovered by generating steam or by supplying heat for air preheating. The heat stream 'QCOOL' represents the energy that could be recovered during gas cooling. This stream is fed to 'QSPLIT', which is used to split the heat stream 'QCOOL' into two heat streams 'QLOSS' and 'QSTEAM'. Two calculator blocks are used, one calculates and sets the amount of heat loss 'QLOSS' and the other calculates and sets the amount of heat available for steam generation or air preheating 'QSTEAM'. The heat loss from the gasifier is assumed to be $3 \%$ of the total heat input [16, 28, 29].

\subsection{Model validation}

The model was validated against the experiments of $\mathrm{Li}$ et al. [27], which were conducted on a pilot scale air-blown biomass CFB gasifier. The fuel used for model validation is hemlock wood. The ultimate and proximate analyses for the wood are given in Table 3.

Table 3

Ultimate and proximate analyses of hemlock (wood) Ultimate Analysis (dry basis) $^{\mathrm{a}}$

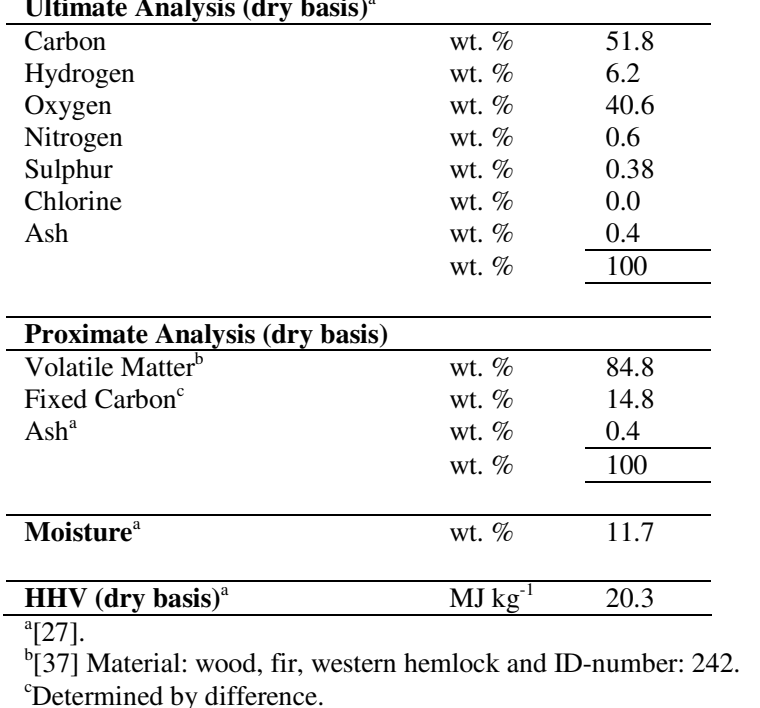

Li et al. [27] reports results for six experimental runs using hemlock wood as input fuel. The input data for three of these runs (run 4,6 and 7) were entered into the model and the predictions were found to be in good agreement with the reported results. For example for run number 4 the model 
predicts the following syn-gas composition: $3.23 \% \mathrm{H}_{2}, 72.82 \% \mathrm{~N}_{2}, 8.9 \% \mathrm{CO}, 15.04 \% \mathrm{CO}_{2}$ and $0.01 \%$ $\mathrm{CH}_{4}$ and for the same input data $\mathrm{Li}$ et al. [27] reports 3.0\% $\mathrm{H}_{2}, 68.4 \% \mathrm{~N}_{2}, 9.6 \% \mathrm{CO}, 17.1 \% \mathrm{CO}_{2}$ and $1.9 \%$ $\mathrm{CH}_{4}$. Experimental run number 7 [27], was chosen for a detailed comparison and analysis. The input data for run number 7 are as follows: input fuel stream mass flow $-33.626 \mathrm{~kg} \mathrm{~h}^{-1}$, gasification temperature - $991 \mathrm{~K}$, and gasification pressure - 1.05 bar.

Table 4 compares the experimental results (run 7) as reported by Li et al. [27] to the model predictions using the input data presented above. The model predictions are in good agreement with the experimental data. For example $\mathrm{H}_{2}, \mathrm{CO}$ and $\mathrm{CO}_{2}$ are predicted within $2.5 \%$ and $\mathrm{N}_{2}$ is under-predicted by 6.8\%. However the $\mathrm{CH}_{4}$ is over-predicted, which causes an error in the calculation of the gas heating value and ultimately the CGE. The under or over-prediction of methane is quite a common problem for modellers; the product gas of fluidised bed gasifiers generally contains tar, which is not considered in equilibrium models, and much more hydrocarbons (especially methane) than predicted [38]. Also, the model done by Giltrap et al. [39] which is a steady state model of a biomass downdraft gasifier, overpredicts $\mathrm{CH}_{4}$ by a substantial amount. The low operating temperature $(991 \mathrm{~K})$ results in high $\mathrm{CH}_{4}$ content and the $\mathrm{CH}_{4}$ content decreases rapidly with temperature (at $\sim 870{ }^{\circ} \mathrm{C}$ the model predicts virtually zero $\left.\mathrm{CH}_{4}\right)$. This is further discussed in section 4 .

Table 4

Experimental results versus model predictions

\begin{tabular}{|c|c|c|}
\hline & $\begin{array}{c}\text { Experimental } \\
\text { (run \# 7) }\end{array}$ & Model \\
\hline Gas composition $^{\mathrm{a}}$ & & \\
\hline $\mathrm{H}_{2}$ & 5.5 & 5.53 \\
\hline $\mathrm{N}_{2}$ & 59.5 & 55.42 \\
\hline $\mathrm{CO}$ & 16.6 & 16.79 \\
\hline $\mathrm{CH}_{4}$ & 3.4 & 7.65 \\
\hline $\mathrm{CO}_{2}$ & 15.0 & 14.62 \\
\hline $\mathbf{H H V}^{\mathrm{b}}$ & 4.82 & 5.87 \\
\hline $\mathbf{C G E}^{\mathrm{c}}$ & 71.4 & 62.61 \\
\hline
\end{tabular}

\section{Sensitivity analysis and discussion}

The model described was used to perform sensitivity analyses. The effects of varying ER, temperature, level of air preheating, biomass moisture and steam injection on product gas composition, gas heating value, and CGE were investigated. During the sensitivity analyses the model input data was 
kept the same as for model validation (run 7 input data), which was presented in section 3.3 , with one parameter being varied at any given time. The CGE $\left(\eta_{C G E}\right)$ is a means of indicating the performance of a gasifier and is defined as: $\eta_{C G E}=\dot{m}_{\text {gas }} \cdot H H V_{\text {gas }} / \dot{m}_{\text {fuel }} \cdot H H V_{\text {fuel }}$. Where $\dot{m}_{\text {gas }}$ and $\dot{m}_{\text {fuel }}$ are the mass flow rate (in $\mathrm{kg} \mathrm{s}^{-1}$ ) of the gas and fuel respectively and $H H V_{\text {gas }}$ and $H H V_{\text {fuel }}$ are the higher heating value (in $\mathrm{kJ} \mathrm{kg}^{-1}$ ) of the gas and fuel respectively.

\subsection{Effect of ER and gasification temperature $\left(T_{g}\right)$}

The influence of ER on product gas composition is illustrated in Fig. 4. $T_{g}$ depends on the amount of air fed to the gasifier, i.e. it is controlled by the ER. As a result, varying ER or $T_{g}$ will have the same effect on product gas composition, heating value, and CGE. For this reason only ER is plotted against product gas composition, heating value and CGE. The corresponding temperatures for each ER are also given. In Fig. $4 \mathrm{H}_{2}, \mathrm{H}_{2} \mathrm{O}, \mathrm{CO}, \mathrm{CO}_{2}$, and $\mathrm{CH}_{4}$ are plotted, with $\mathrm{H}_{2} \mathrm{~S}$ and $\mathrm{NH}_{3}$ omitted, first of all because of their very low content and second because they would be removed by downstream air pollution control equipment in a gasification plant. All gas components are plotted on a dry basis except for water vapour. The nitrogen $\left(\mathrm{N}_{2}\right)$ content is not displayed; its value may be calculated by summing the other components and subtracting this from $100 \%$. The $\mathrm{N}_{2}$ content varied between 53 and $61 \%$ over the ER and $T_{g}$ range. The most interesting point from Fig. 4 is that both $\mathrm{H}_{2}$ and $\mathrm{CO}$ reach a maximum at an ER of 0.35 or at a temperature of $874{ }^{\circ} \mathrm{C}$. After this peak their contents decrease steadily. $\mathrm{H}_{2} \mathrm{O}$ increases over the whole range but experiences a small decrease close to the point of maximum $\mathrm{H}_{2}$ and $\mathrm{CO} \mathrm{CO}_{2}$ decreases rapidly up to an ER of 0.35 and then increases slowly. $\mathrm{CH}_{4}$ decreases and eventually reaches zero between an ER of 0.4 and 0.45 or a temperature of 1046 and $1195{ }^{\circ} \mathrm{C}$. These trends may be explained as follows:

- The Boudouard reaction (R2) is endothermic; therefore as the temperature rises, so does the amount of $\mathrm{CO}_{2}$ reacted with char to produce $\mathrm{CO}$. For ERs up to 0.35 sufficient char is available for the Boudouard reaction but for ERs greater than this there is insufficient char, so $\mathrm{CO}$ decreases and $\mathrm{CO}_{2}$ increases.

- The water-gas reaction (R3) is endothermic, which means for increasing ER and temperature CO and $\mathrm{H}_{2}$ production are increased and more char and $\mathrm{H}_{2} \mathrm{O}$ are consumed. 
- The methanation reaction (R4) is exothermic, which means as ER and $T_{g}$ increase the production of $\mathrm{CH}_{4}$ decreases, which in turn leaves more $\mathrm{H}_{2}$ in the gas.

- The $\mathrm{CO}$ is reacted with available $\mathrm{O}_{2}(\mathrm{R} 5)$ producing $\mathrm{CO}_{2}$.

- $\mathrm{H}_{2}$ is reacted with available $\mathrm{O}_{2}(\mathrm{R} 6)$ producing $\mathrm{H}_{2} \mathrm{O}$. This reaction produces more water than is used up by the reactions (R3) and (R8) because the $\mathrm{H}_{2} \mathrm{O}$ content increases over the whole ER and temperature range. The slight drop in $\mathrm{H}_{2} \mathrm{O}$ occurs at an ER of 0.34 and a $T_{g}$ of $837{ }^{\circ} \mathrm{C}$. One possible explanation would be that at a sufficiently high temperature reaction (R8) begins to consume more water than is produced by reaction (R6); however, this trend is short-lived because the other reactant required for this reaction, $\mathrm{CH}_{4}$ is decreasing rapidly.

- The $\mathrm{CO}$ shift reaction (R7) being exothermic, produces less $\mathrm{CO}_{2}$ and $\mathrm{H}_{2}$ at higher temperatures, which means less $\mathrm{CO}$ and $\mathrm{H}_{2} \mathrm{O}$ are consumed.

- The $\mathrm{CH}_{4}$ is reduced by the steam-methane reforming reaction (R8). This reaction is endothermic meaning the forward reaction is favoured as temperature increases. Hence, $\mathrm{CH}_{4}$ and $\mathrm{H}_{2} \mathrm{O}$ decrease while $\mathrm{H}_{2}$ and $\mathrm{CO}$ increase.

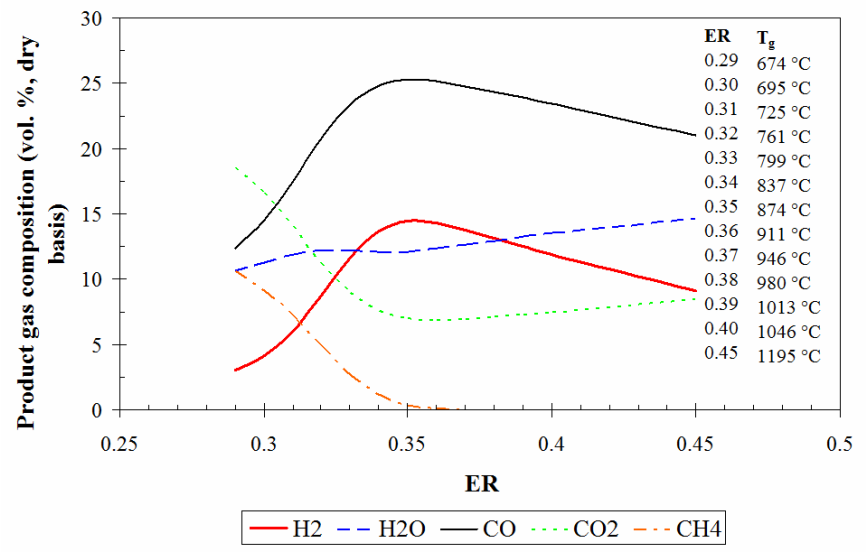

Fig. 4. Effect of ER on product gas composition.

Commercial fluidised bed biomass gasifiers operate in the temperature range $800-1000{ }^{\circ} \mathrm{C}$, which for this model corresponds to an ER range of $0.33-0.38$. ER values higher than 0.3 have to be used to get tar contents below $2 \mathrm{~g} \mathrm{~m}^{-3}$ [40]. Taking these points into consideration the authors recommend operation at $\mathrm{ER}=0.34$ to 0.35 or $T_{g}=837$ to $874{ }^{\circ} \mathrm{C}$.

The influence of ER on product gas heating value and CGE is shown in Fig. 5. The gas HHV on a mass basis and the CGE on a HHV basis are plotted against ER. It is evident that the heating value 
decreases with increasing ER. The HHV is high for low ERs due to the high $\mathrm{CH}_{4}$ content. The CGE increases between an ER of 0.29 and 0.34 , it reaches a maximum value of $66.1 \%$ at an ER of 0.34 and then decreases steadily. It is worth noting that the point of maximum CGE corresponds to the point of maximum $\mathrm{H}_{2}$ and $\mathrm{CO}$ content in Fig. 4. The CGE for an ER of 0.31 as reported by Li et al. [27] is indicated on the plot. It is indicated for comparison with the model prediction at the same ER value.

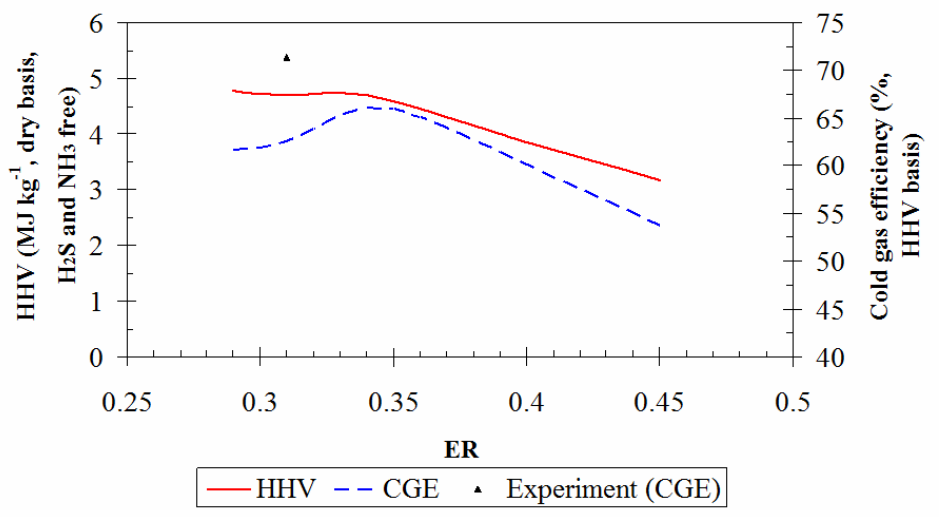

Fig. 5. Effect of ER on gas HHV on a mass basis and CGE on a HHV basis ( $\boldsymbol{\Delta}$ : indicates CGE as reported by Li et al. [27]).

\subsection{Effect of air preheating}

Air preheating is a means of increasing the conversion efficiency of the gasification process. The sensible heat in the air causes a rise in the gasification temperature, which in turn influences the product gas composition, causing an increase in the production of combustible gases, $\mathrm{H}_{2}$ and CO. This change in syn-gas composition affects the gas HHV and hence the gasifier CGE. Air preheating offers an alternative and more economical approach than oxygen blown systems [41]. The overall efficiency of the process on a thermal basis would be increased if the heat required for air preheating was recovered from the gas cooling section of the plant. Use of high temperature air as an oxidant achieves downsizing of the plant [42]. Downsizing is achieved because a smaller volume of air is needed to bring the gasifier to the required operating temperature, which in turn reduces the size of the reactor and gas cleanup system needed.

The influence of air preheating on the reactor or gasification temperature $T_{g}$ was investigated over the complete ER range. It was found that $T_{g}$ increased almost linearly with air temperature $\left(T_{a}\right)$ for 
all ERs. It was discovered that a limit on the level of air preheating exists for each ER. This level is limited by the effectiveness of the heat exchange equipment used to transfer the heat from the syn-gas to the air but it is also limited by the operating temperature constraint of fluidised beds. Fluidised bed biomass gasifiers should not be operated over $1000{ }^{\circ} \mathrm{C}$, so as to ensure that the ash melting temperature is not reached, which would cause agglomeration and de-fluidisation. It was found that at high ERs air preheating is limited to a low level, e.g. at an ER of 0.37 a $T_{a}$ no more than $114{ }^{\circ} \mathrm{C}$ would be recommended because the corresponding $T_{g}$ is $987{ }^{\circ} \mathrm{C}$ whereas for an ER of 0.29 the air could in theory be heated to $825{ }^{\circ} \mathrm{C}$ as the $T_{g}$ stays below the limit at a value of $978{ }^{\circ} \mathrm{C}$.

The influence of $T_{a}$ on product gas composition is shown in Fig. 6. The product gas composition for an ER value of 0.29 is plotted against $T_{a}$. The gas composition changes reflect the change in the gasifier temperature. The rising temperature promotes the products of the endothermic reactions, (R2), (R3) and (R8), and simultaneously the reactants of the exothermic reactions (R4) and (R7). A detailed discussion on the effects of gasifier temperature was given in section 4.1. The major conclusion drawn from this sensitivity analysis is that $T_{a}$ has a greater influence on the product gas composition for low ERs. For an ER of $0.29 \mathrm{CO}$ and $\mathrm{H}_{2}$ content increases 17.3 and 15.8 percentage points respectively over the $T_{a}$ range whereas for an ER of $0.34 \mathrm{CO}$ and $\mathrm{H}_{2}$ content increases by only 2.7 and 1.8 percentage points respectively over the same temperature range. It was also found that $T_{a}$ has a significant influence on composition only up to a certain level, after which additional preheating has little effect. For an ER of 0.29 this $T_{a}$ is high at a value of $\sim 560{ }^{\circ} \mathrm{C}$ but for an ER of 0.34 it is significantly lower at $\sim 200{ }^{\circ} \mathrm{C}$. This finding agrees with published work [43, 44]. Lucas et al. [43] reported that the $\mathrm{H}_{2}$ rises with increasing air preheat temperature but exhibits no rise between 700 and $830{ }^{\circ} \mathrm{C}$. Yang et al. [44] refers to a critical $T_{a}$ above which air preheating is no longer efficient if the purpose is to maximise the yield of gaseous products. This critical $T_{a}$ for $\mathrm{CO}$ and $\mathrm{H}_{2}$ was reported as $530{ }^{\circ} \mathrm{C}$. The results of this work indicate a critical temperature of $\sim 560{ }^{\circ} \mathrm{C}$ for an ER of 0.29 . 


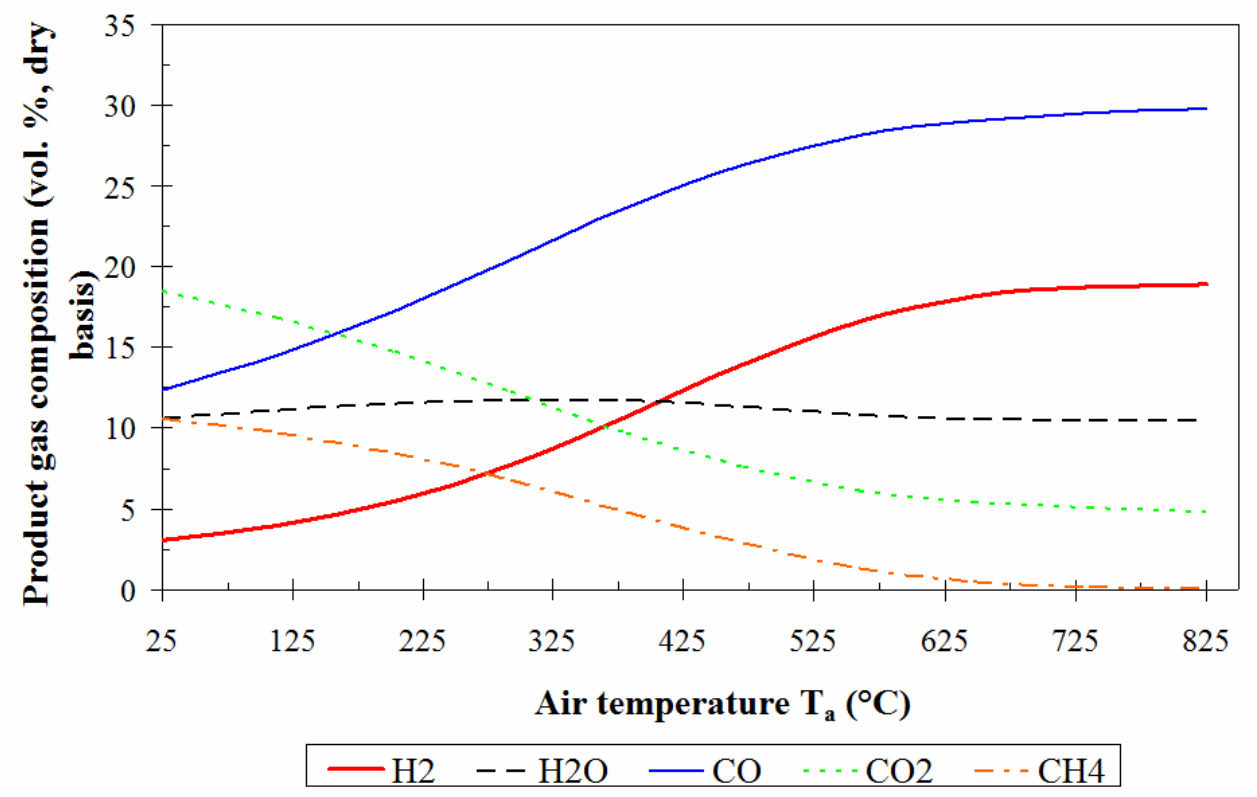

Fig. 6. Effect of $\mathrm{T}_{\mathrm{a}}$ on product gas composition for $\mathrm{ER}=0.29$.

The influence of air preheating on product gas heating value and CGE is shown in Fig. 7. The gas HHV on a mass basis and the CGE on a HHV basis, plot (a) and (b) of Fig. 7 respectively, were plotted against $T_{a}$ for the complete range of ER. As expected, the gas heating value increases with $T_{a}$. The increase is in line with the gas composition change for each ER, i.e. the increase is greater for low ERs than for high ERs due to the greater change in gas composition for low ERs. The CGE trends are in agreement with the changes in gas composition and HHV. $T_{a}$ has a significant influence on CGE at low ER values. Its influence ceases for ERs greater than 0.35 . As already seen for gas composition, $T_{a}$ has a significant effect on CGE only up to a certain level, after which additional preheating has little influence. For an ER of 0.29 this $T_{a}$ is high at a value of $\sim 650{ }^{\circ} \mathrm{C}$ but for an ER of 0.33 it is significantly lower at $\sim 290^{\circ} \mathrm{C}$. For an ER of 0.34 , which is a point of interest because it was the point of maximum CGE for gasification without air preheating, the CGE increases from 66.1 to $67.2 \%$ for a $T_{a}$ of $\sim 110{ }^{\circ} \mathrm{C}$ and then increases by a lesser degree to $67.7 \%$ for a $T_{a}$ of $\sim 200{ }^{\circ} \mathrm{C}$. 

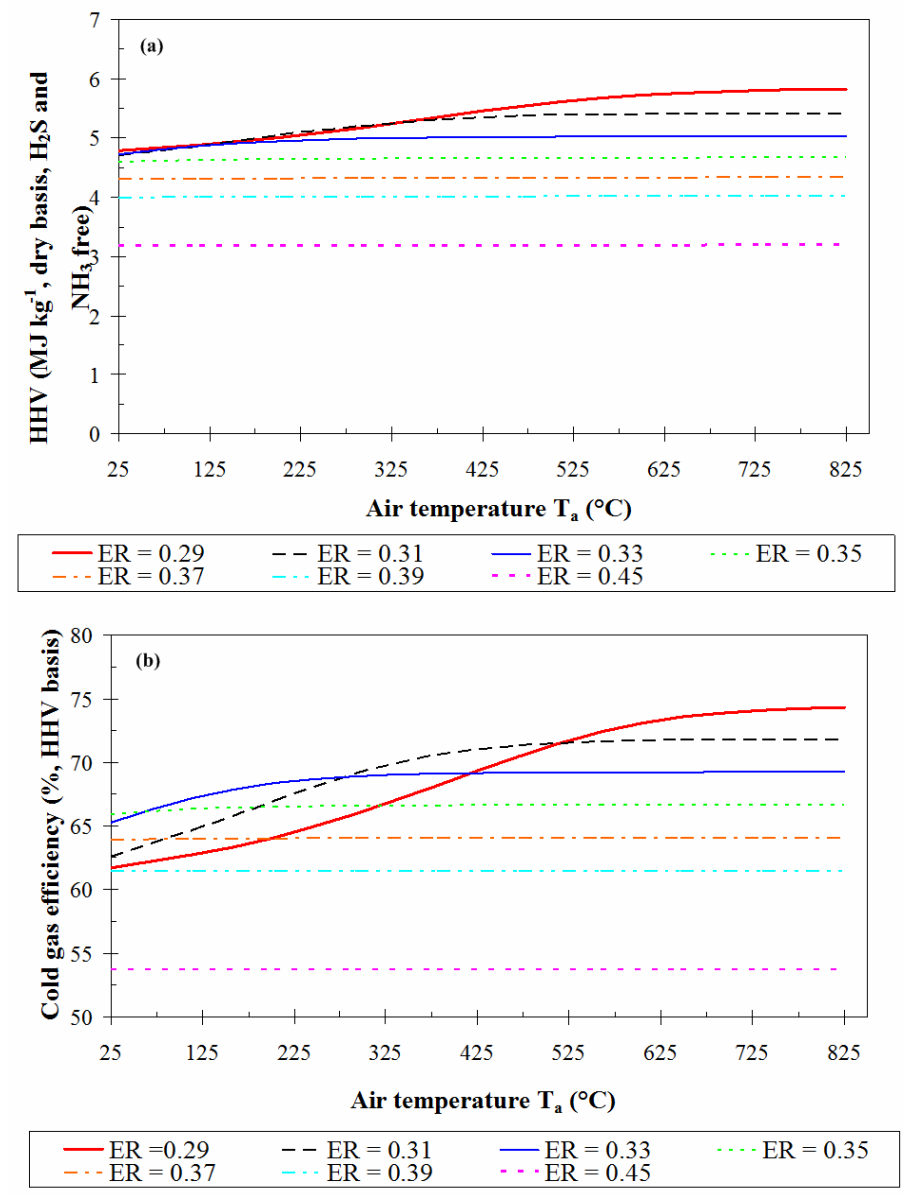

Fig. 7. Effect of $T_{a}$ on (a) gas HHV on a mass basis and (b) CGE on a HHV basis for complete ER range.

\subsection{Effect of biomass moisture and injected steam}

The effect of fuel bound moisture on gasifier performance for $\mathrm{ER}=0.34$ is shown in Fig. 8 (a). The moisture level was varied over a realistic range for woody biomass $(5-30 \%)$ and as expected increasing the moisture content degrades gasifier performance. Both syn-gas HHV and gasifier CGE reach their maximum level, $5.138 \mathrm{MJ} \mathrm{kg}^{-1}$ and $73.81 \%$ respectively, at the lowest moisture content (5\%). The gas heating value and CGE decrease over the entire moisture range, for comparison $\mathrm{HHV}=3.338 \mathrm{MJ}$ $\mathrm{kg}^{-1}$ and CGE $=44.24 \%$ at a moisture content of $30 \%$. These trends are a direct result of changes in the syn-gas composition with moisture. The rising $\mathrm{H}_{2} \mathrm{O}$ content is the main cause for the decline in syn-gas HHV. $\mathrm{CO}$ and $\mathrm{CH}_{4}$ are shifted and reformed respectively with the additional $\mathrm{H}_{2} \mathrm{O}$ decreasing their contents and producing $\mathrm{CO}_{2}$. There is little change in $\mathrm{H}_{2}$ content at this ER however at lower ERs $\mathrm{H}_{2}$ content was found to increase with moisture level. Similar performance trends were seen for other ERs but maximum gasifier performance was predicted for an ER range of 0.34 to 0.35 . 
The influence of steam injection on gasifier performance for an ER of 0.34 is illustrated in Fig. 8 (b). The steam injection rate was varied from 0 to $10.5 \mathrm{~kg} \mathrm{~h}^{-1}$ [27]. The syn-gas HHV decreases only slightly from 4.69 to $4.62 \mathrm{MJ} \mathrm{kg}^{-1}$ and gasifier CGE increases from 66.1 to $66.5 \%$. This small increase in CGE is due to increased syn-gas mass flow rate. As was seen for increasing moisture level, steam injection causes a rise in $\mathrm{H}_{2} \mathrm{O}$ content, which results in a lower syn-gas $\mathrm{HHV}$. CO and $\mathrm{CH}_{4}$ are shifted and reformed respectively with the additional $\mathrm{H}_{2} \mathrm{O}$ decreasing their contents and producing $\mathrm{CO}_{2}$. The most important effect of steam injection is the rise in $\mathrm{H}_{2}$ content, in this case $\mathrm{H}_{2}$ increases by $3 \%$ (13.7 to $16.7 \%$ ) over the range of steam injection. The gasifier temperature will decrease with increasing steam injection due to the highly endothermic reforming and water-gas reactions (R3 and R8) unless heat is supplied from an external source. A decrease in temperature is undesirable as this would degrade gasifier performance and could lead to high tar yield. Similar performance trends were seen for other ERs but maximum increase in $\mathrm{H}_{2}$ content was predicted for an ER range of 0.34 to 0.35 .
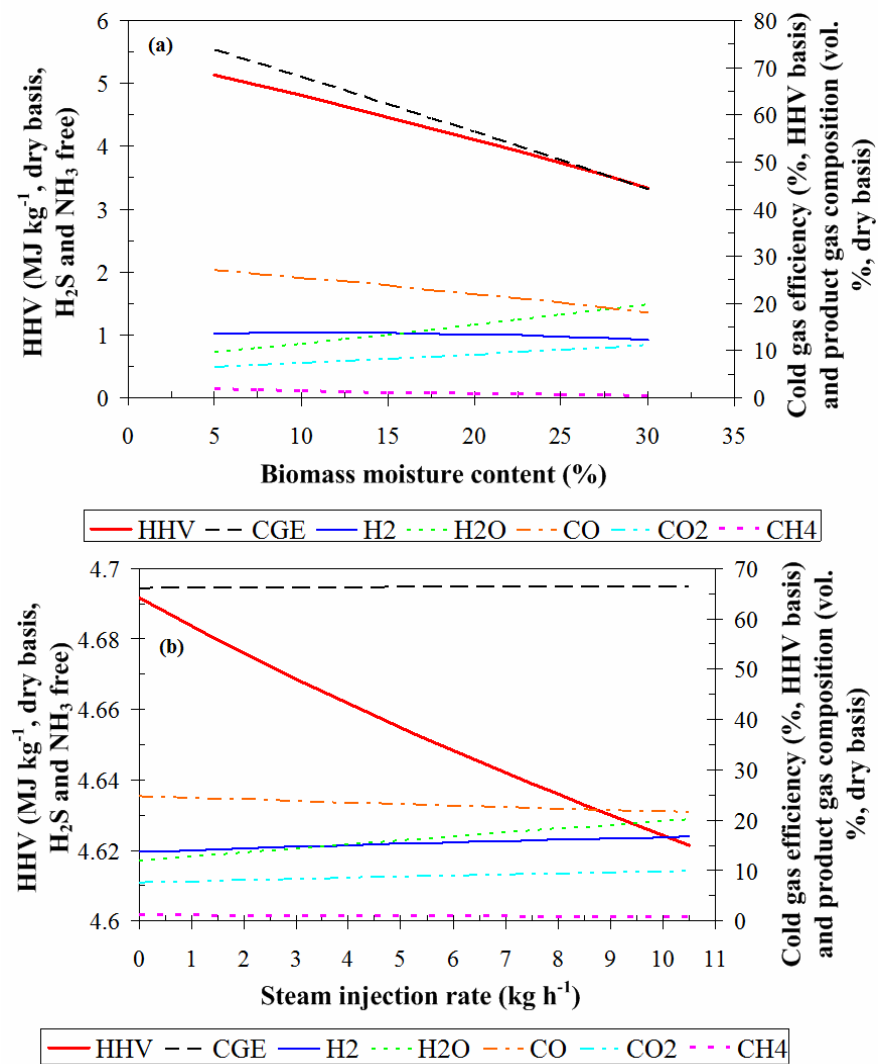

Fig. 8. Effect of (a) biomass moisture content and (b) steam injection rate on product gas composition, gas HHV on a mass basis and CGE on a HHV basis for $\mathrm{ER}=0.34$. 
The main conclusion from the analysis above is that injected steam, although chemically equivalent, has better reactivity than fuel bound moisture. A possible reason for this is that the time it takes to bring the moisture up to the gasifier temperature is greater than the residence time and therefore the moisture does not participate in the chemical reactions. This finding agrees with other work [27]. The results indicate that the input fuel should be pre-dried to ensure low moisture content and if a $\mathrm{H}_{2}$ rich syn-gas is required steam injection should be employed. Air preheating should be considered when using high moisture fuels and steam injection because air preheating causes an increase in the gasifier temperature (see section 4.2), which would in turn offset both fuel pre-drying and the temperature decrease as a result of steam injection.

\section{Conclusions}

A computer simulation model of a circulating fluidised bed biomass gasifier was developed using ASPEN Plus. The model was calibrated against experimental data. The restricted equilibrium method was used. In addition the results obtained from the sensitivity analyses are in good agreement with published work. Therefore, it may be said that the model is capable of predicting accurately gasifier performance over a wide range of operating conditions. The effects of varying ER, temperature, level of air preheating, biomass moisture and steam injection on product gas composition, gas heating value, and CGE were investigated, the results of which revealed the following:

- Without air preheating, the optimum operating conditions were found to be: $\mathrm{ER}=0.34$ to 0.35 and gasifier temperature $=837$ to $874{ }^{\circ} \mathrm{C}$.

- The syn-gas heating value decreases with increasing ER.

- Without air preheating, the CGE reaches a maximum value of $66.1 \%$ at an ER of 0.34 .

- Air preheating increases the production of combustible gases, $\mathrm{H}_{2}$ and $\mathrm{CO}$, which increases the product gas heating value and the gasifier CGE.

- $\quad$ Air preheating is more effective at low ERs. It should not be used for ERs greater than 0.35.

- A critical $T_{a}$ exists after which additional preheating has little influence. This temperature is high for low ERs and low for high ERs.

- For ER = 0.34, which is the point of maximum CGE for gasification without air preheating, the CGE increases 1.6 percentage points for a low level of air preheating $\left(T_{a}=200{ }^{\circ} \mathrm{C}\right)$. 
- If economical, the gasifier could be operated using very high temperature air, which would mean it could operate using a low ER. A lower ER means reduced volume and hence, the size and cost of the gasifier, gas cleanup system and other plant components would be reduced.

- Steam has better reactivity than fuel bound moisture.

- Increasing moisture degrades gasifier performance therefore the input fuel should be pre-dried.

- Steam injection should be employed if a $\mathrm{H}_{2}$ rich syn-gas is desired.

In a future study, the biomass gasifier model presented here will be integrated with a high temperature fuel cell stack model and balance of plant models all developed in ASPEN Plus.

\section{References}

[1] Government White Paper: Delivering a Sustainable Energy Future for Ireland, Dept. of Communications, Marine, and Natural Resources, 2007.

[2] World Energy Technology Outlook - 2050. European Commission, 2006.

[3] World Energy Outlook. International Energy Agency, 2006.

[4] Rezaiyan J., Cheremisinoff N. Gasification Technologies: A Primer for Engineers and Scientists. FL: Taylor \& Francis / CRC Press, 2005.

[5] Ong'iro A.O. Techno-Economic Modeling Of Integrated Advanced Power Cycles. PhD Thesis, Technical University of Nova Scotia, 1996.

[6] Schuster G., Loffler G., Weigl K., Hofbauer H. Biomass steam gasification - an extensive parametric modeling study. Bioresource Technology 2001;77:71-9.

[7] Kaushal P., Proll T., Hofbauer H. Model development and validation: Co-combustion of residual char, gases and volatile fuels in the fast fluidized combustion chamber of a dual fluidized bed biomass gasifier. Fuel 2007;86:2687-95.

[8] Murakami T., Xu G., Suda T., Matsuzawa Y., Tani H., Fujimori T. Some process fundamentals of biomass gasification in dual fluidized bed. Fuel 2007;86:244-55.

[9] Shen L., Gao Y., Xiao J. Simulation of hydrogen production from biomass gasification in interconnected fluidized beds. Biomass and Bioenergy; In Press, Corrected Proof.

[10] Higman C., van der Burgt M. Gasification. Boston: Gulf Professional Publishing, 2003.

[11] Di Blasi C., Signorelli G., Di Russo C., Rea G. Product Distribution from Pyrolysis of Wood and Agricultural Residues. Ind. Eng. Chem. Res. 1999;38:2216-24.

[12] Pickett M.M. Modeling The Performance And Emissions Of British Gas/Lurgi-Based Integrated Gasification Combined Cycle Systems. M.Sc. Thesis, Civil Engineering, North Carolina State University, 2000.

[13] Akunuri N.V. Modeling The Performance, Emissions, And Costs Of Texaco Gasifier-Based Integrated Gasification Combined Cycle Systems. M.Sc. Thesis, Civil Engineering, North Carolina State University, 1999.

[14] Craig K.R., Mann M.K. Cost and Performance Analysis of Biomass-Based Integrated Gasification Combined-Cycle (BIGCC) Power Systems. NREL, US DOE, 1996.

[15] Dellepiane D., Bosio B., Arato E. Clean energy from sugarcane waste: feasibility study of an innovative application of bagasse and barbojo. Journal of Power Sources 2003;122:47-56.

[16] Donolo G., Simon G.D., Fermeglia M. Steady state simulation of energy production from biomass by molten carbonate fuel cells. Journal of Power Sources 2006;158:1282-9.

[17]. de Jong W., Unal O., Andries J., Hein K.R.G., Spliethoff H. Biomass and fossil fuel conversion by pressurised fluidised bed gasification using hot gas ceramic filters as gas cleaning. Biomass and Bioenergy 2003;25:59-83.

[18] Kuchonthara P., Bhattacharya S., Tsutsumi A. Combination of thermochemical recuperative coal gasification cycle and fuel cell for power generation. Fuel 2005;84:1019-21. 
[19] Mathieu P., Dubuisson R. Performance analysis of a biomass gasifier. Energy Conversion and Management 2002;43:1291-9.

[20] Prins M.J., Ptasinski K.J., Janssen F.J.J.G. More efficient biomass gasification via torrefaction. Energy 2006;31:3458-70.

[21] Suwanwarangkul R., Croiset E., Pritzker M.D., Fowler M.W., Douglas P.L., Entchev E. Modelling of a cathode-supported tubular solid oxide fuel cell operating with biomass-derived synthesis gas. Journal of Power Sources 2007; 166:386-99.

[22] Tijmensen M.J.A., Faaij A.P.C., Hamelinck C.N., van Hardeveld M.R.M. Exploration of the possibilities for production of Fischer Tropsch liquids and power via biomass gasification. Biomass and Bioenergy 2002;23:129-52.

[23] Zhu Y. Evaluation Of Gas Turbine And Gasifier-Based Power Generation System. PhD Thesis, Civil, Construction, and Environmental Engineering, North Carolina State University, 2004.

[24] Zanzi R., Sjostrom K., Bjornbom E. Rapid pyrolysis of agricultural residues at high temperature. Biomass and Bioenergy 2002;23:357-66.

[25] Moreea-Taha R., Modelling and simulation for coal gasification. IEA Coal Research, 2000.

[26] Zhang R., Basu P. A simple model for prediction of solid collection efficiency of a gas-solid separator. Powder Technology 2004;147:86-93.

[27] Li X.T., Grace J.R., Lim C.J., Watkinson A.P., Chen H.P., Kim J.R. Biomass gasification in a circulating fluidized bed. Biomass and Bioenergy 2004;26:171-93.

[28] Corella J., Toledo J.M., Molina G. Calculation of the conditions to get less than $2 \mathrm{~g} \operatorname{tar} / \mathrm{mn} 3$ in a fluidized bed biomass gasifier. Fuel Processing Technology 2006;87:841-6.

[29] Hughes W.E. Biomass Integrated- Gasification / Gas Turbine Power Generation In Zimbabwe. PhD Thesis, Mechanical and Aerospace Engineering, Princeton University, 1998.

[30] Chen J. Optimization Of Cost And Emissions Of A KRW-Gasifier Based IGCC System Under Variability And Uncertainty. M.Sc. Thesis, Civil, Construction and Environmental Engineering, North Carolina State University, 2003.

[31] Stevens D.J., Hot Gas Conditioning: Recent Progress With Larger-Scale Biomass Gasification Systems. NREL, US DOE, 2001.

[32] Prins M. Thermodynamic analysis of biomass gasification and torrefaction. Technische Universiteit Eindhoven, 2005.

[33] Corella J., Sanz A. Modeling circulating fluidized bed biomass gasifiers. A pseudo-rigorous model for stationary state. Fuel Processing Technology 2005;86:1021-53.

[34] Demirbaş A. Carbonization ranking of selected biomass for charcoal, liquid and gaseous products. Energy Conversion and Management 2001;42:1229-38.

[35] Gumz W. Gas producers and blast furnaces. New York: John Wiley \& Sons, 1950.

[36] Ståhl K., Värnamo Demonstration Plant - A demonstration plant for biofuel-fired combined heat and power generation based on pressurized gasification. The Demonstration Programme 19962000. European Commission, Swedish Energy Agency, Sydkraft AB, 2001.

[37] ECN. Phyllis, database for biomass and waste. Available at: http://www.ecn.nl/phyllis.

[38] Prins M.J., Ptasinski K.J., Janssen F.J.J.G. From coal to biomass gasification: Comparison of thermodynamic efficiency. Energy 2007;32:1248-59.

[39] Giltrap D.L., McKibbin R., Barnes G.R.G. A steady state model of gas-char reactions in a downdraft biomass gasifier. Solar Energy 2003;74:85-91.

[40] Sanz A., Corella J. Modeling circulating fluidized bed biomass gasifiers. Results from a pseudorigorous 1-dimensional model for stationary state. Fuel Processing Technology 2006;87:247-58.

[41] Pian C.C.P., Yoshikawa K. Development of a high-temperature air-blown gasification system. Bioresource Technology 2001;79:231-41.

[42] Sugiyama S., Suzuki N., Kato Y., Yoshikawa K., Omino A., Ishii T., et al. Gasification performance of coals using high temperature air. Energy 2005;30:399-413.

[43] Lucas C., Szewczyk D., Blasiak W., Mochida S. High-temperature air and steam gasification of densified biofuels. Biomass and Bioenergy 2004;27:563-75.

[44] Yang W., Ponzio A., Lucas C., Blasiak W. Performance analysis of a fixed-bed biomass gasifier using high-temperature air. Fuel Processing Technology 2006;87:235-45. 